\title{
The application of walking training in the rehabilitation of patients after coronary artery bypass grafting
}

\author{
Dorota Sobczak, Piotr Dylewicz \\ Department of Cardiac Rehabilitation, University School of Physical Education in Poznan, Poland
}

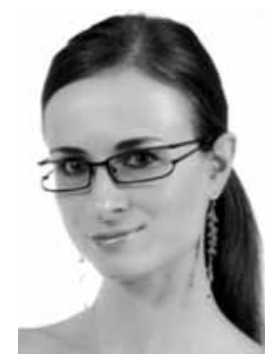

Kardiochirurgia i Torakochirurgia Polska 2015; 12 (3): 275-287

\begin{abstract}
Walking is regarded as one of the most common and utilitarian activities of everyday life. Rehabilitation programs developed on the basis of this form of activity often constitute the primary method of rehabilitating patients after coronary artery bypass grafting. This paper provides a review of literature concerning various forms of walking training, discussing their impact on the parameters of exercise capacity and verifying the training methods with regard to the current guidelines. Attention is drawn to the diversity of the exercise protocols applied during the early and late stages of rehabilitation and pre-rehabilitation programs including: treadmill walking, walking down the corridor, treadmill walking enriched with virtual reality, and walking as an element of training sessions consisting of many different forms of activities. Exercise protocols were also analyzed in terms of their safety, especially in the case of high-intensity interval training. Despite the variety of the available rehabilitation programs, the training methodology requires constant improvement, particularly in terms of load dosage and the supervision of training sessions.
\end{abstract}

Key words: walking training, rehabilitation, coronary artery bypass grafting.

\section{Introduction}

In accordance with the current recommendations, coronary artery bypass grafting (CABG) procedures constitute a highly effective method of treatment for multivessel coronary artery disease as well as its one- or two-vessel forms if percutaneous coronary intervention $(\mathrm{PCI})$ is contraindicated or fails [1-3]. Globally, the number of performed CABG procedures continues to rise. Surgical procedures are performed in increasingly older patients who are often burdened with concomitant diseases and are physically unfit.

\section{Streszczenie}

Marsz jest uważany za jedną z najpowszechniejszych i najbardziej utylitarnych aktywności dnia codziennego. Programy usprawniania tworzone w oparciu o tę formę ruchu niejednokrotnie stanowią podstawową metodę rehabilitacji pacjentów poddanych zabiegowi pomostowania aortalno-wieńcowego. W niniejszej pracy dokonano przeglądu literatury z zakresu aplikowanych form treningów marszowych, omówiono ich wpływ na parametry wydolnościowe chorych oraz zweryfikowano je pod kątem zgodności z aktualnymi wytycznymi. Zwrócono uwagę na różnorodność stosowanych programów treningowych we wczesnej i późnej fazie rehabilitacji oraz prerehabilitacji, obejmujących marsz prowadzony na bieżni, marsz realizowany w klasycznej formie korytarzowej, marsz wzbogacony o projekcję wirtualnej rzeczywistości oraz marsz stanowiący element sesji treningowej składającej się z wielu różnorodnych form ruchu. Programy usprawniania przeanalizowano również pod kątem bezpieczeństwa ich stosowania, w szczególności w odniesieniu do treningów interwałowych o wysokiej intensywności. Pomimo różnorodności dostępnych metod usprawniania wciąż istnieje konieczność doskonalenia przede wszystkim metodyki prowadzenia treningów marszowych, a w szczególności dawkowania obciążeń oraz nadzoru sesji. Stowa kluczowe: trening marszowy, rehabilitacja, pomostowanie aortalno-wieńcowe.

Consequently, the number of patients requiring rehabilitation with methods appropriate for their medical situation continues to increase. Hence there is a need for verifying the existing methods of rehabilitation and creating new programs directed especially at patients characterized by a higher risk of complications $[4,5]$.

\section{Therapeutic effects of walking training}

Walking is considered to be the most utilitarian and the most common of everyday activities [6]. Rehabilitation pro- 
grams based on this form of movement are effective in cardiac patients, including those after coronary artery bypass grafting [6-17]. However, the effectiveness of training does not always go hand in hand with its safety. By conducting a comparative analysis of the efficacy of higher-intensity interval training and moderate-intensity continuous training (Table I), Kateyian et al. [16] brought attention to one of the key issues associated with the clinical application of higher-intensity interval training: none of the programs were sufficiently analyzed, especially with regard to their safety, to become integral components of the $2^{\text {nd }}$ stage of cardiac rehabilitation. The authors also pointed to the significant differences between the programs (e.g., regarding the time during which the patient is exposed to high loads) as well as to the fact that recruitment to this type of training includes patients in relatively good clinical condition and with better fitness parameters in comparison to patients included in standard rehabilitation programs. Despite achieving favorable rehabilitation results with the interval method (Table II), the authors underscored that this does not entail that the employed training program is safe for the patients or that it does not increase the risk of adverse clinical events. High-intensity interval training appears to be a method for progressive fitness improvement, but only on the condition that its performance remains under strict supervision.

The issue of the effectiveness and safety of interval training was also mentioned by Rognmo et al. [9]. Despite proving the advantage of interval training over continuous training in terms of improving peak oxygen uptake (Table II), other authors [6] also underscored the need for conducting further studies that would confirm the safety of the employed methods. Although the average Borg Rating of Perceived Exertion after exercise was similar in both groups (respectively, 14.4 and 13.5 for interval training and continuous training), the critical issue remains the safety of the recommended physical activity, whose intensity reaches $90 \% \mathrm{VO}_{2 \text { peak }}($ Table I). One should bear in mind that cardiovascular patients are more susceptible to sudden cardiac events during intensive exertion than healthy persons [18]. Another important issue is the selection of optimal training duration depending on its type. Interval training of relatively high intensity requires shorter sessions in order to ensure patient safety. Notwithstanding, due to the higher increase of peak oxygen uptake during interval training (Table II), resulting in improved fitness, which constitutes a significant factor for improving survival $[19,20]$, interval walking training should become one of the elements of routine patient rehabilitation [9].

Aside from the improvement of fitness, the advantages of interval programs appear to include the duration of the beneficial changes. When comparing the effectiveness of interval and continuous walking training with regard to the improvement of fitness (Table I), Moholdt et al. [14] demonstrated that, after 4 weeks of rehabilitation, peak oxygen uptake increased significantly in both groups. However, only in the interval training group did the effect per- sist and even continue to improve over the next 6 months (Table II). The authors explain the phenomenon by the patients' adherence to the provided recommendations concerning physical activity after discharge from the hospital. The patients exercising with the interval method reported more frequent participation in higher-intensity training in comparison to the continuous training group. The authors also point to the significance of the moment at which the patients leave the hospital/rehabilitation center, as it becomes for them a turning point for choosing a more healthy lifestyle and continuing physical activity.

High-intensity training used in the rehabilitation of CABG patients does not necessarily have to involve interval training. Continuous walking training programs are considered a safe method of rehabilitation [18]; therefore, in practice, they are used more often than interval programs [9]. Continuous high-intensity aerobic exercise has also been used in clinical practice by Bahremand et al. [17]. As the influence of this form of rehabilitation on diastolic cardiac function had been unclear, the authors attempted to investigate it. Some of the previously conducted studies reported a positive influence of the training on diastolic parameters [21-23], prevention of further loss of diastolic function [24], or no influence on the diastolic parameters of the left ventricle of the heart [25-27]. In their study group, Bahremand et al. [17] noted significantly better diastolic parameters, which probably resulted from the employed rehabilitation program (Table II). The degree of dysfunction was reduced as well: before rehabilitation, none of the patients had normal diastolic function, while $27.3 \%$ had grade $2-3$ dysfunction; after the training cycle, $36.4 \%$ of the participants had normal diastolic function, and only $13.7 \%$ had grade 2-3 dysfunction. No statistically significant association was found between the improvement of the grade of dysfunction and the typical risk factors: female sex, advanced age, systolic hypertension, hyperlipidemia, and diabetes.

The type of training and the degree of its intensity are among the most often analyzed parameters, but there are more. Some researchers have investigated the mechanisms of physiological adaptation to increasing loads [7, 8, 10-12]. Such analysis has been conducted by Goodman et al. [7], who demonstrated that the fitness improvement achieved in their study group, which probably resulted from the employed rehabilitation program (Table I), can be attributed primarily to the participation of peripheral compensatory mechanisms, with limited support of the slightly improving left ventricular function. The obtained results (Table II) indicate that there is a relationship between peripheral vasodilatory reserve and $\mathrm{VO}_{2 \max }$, confirming the results of previous studies [28, 29].

Hitoshi et al. evaluated the influence of walking training on respiratory parameters and cardiac output [8]. The authors reported dyspnea to be the most frequent complaint of patients in response to increased physical activity; the symptom probably resulted from changes in the analyzed parameters. In patients after CABG, deep breathing may be accompanied by chest pain as a result of sternotomy. 


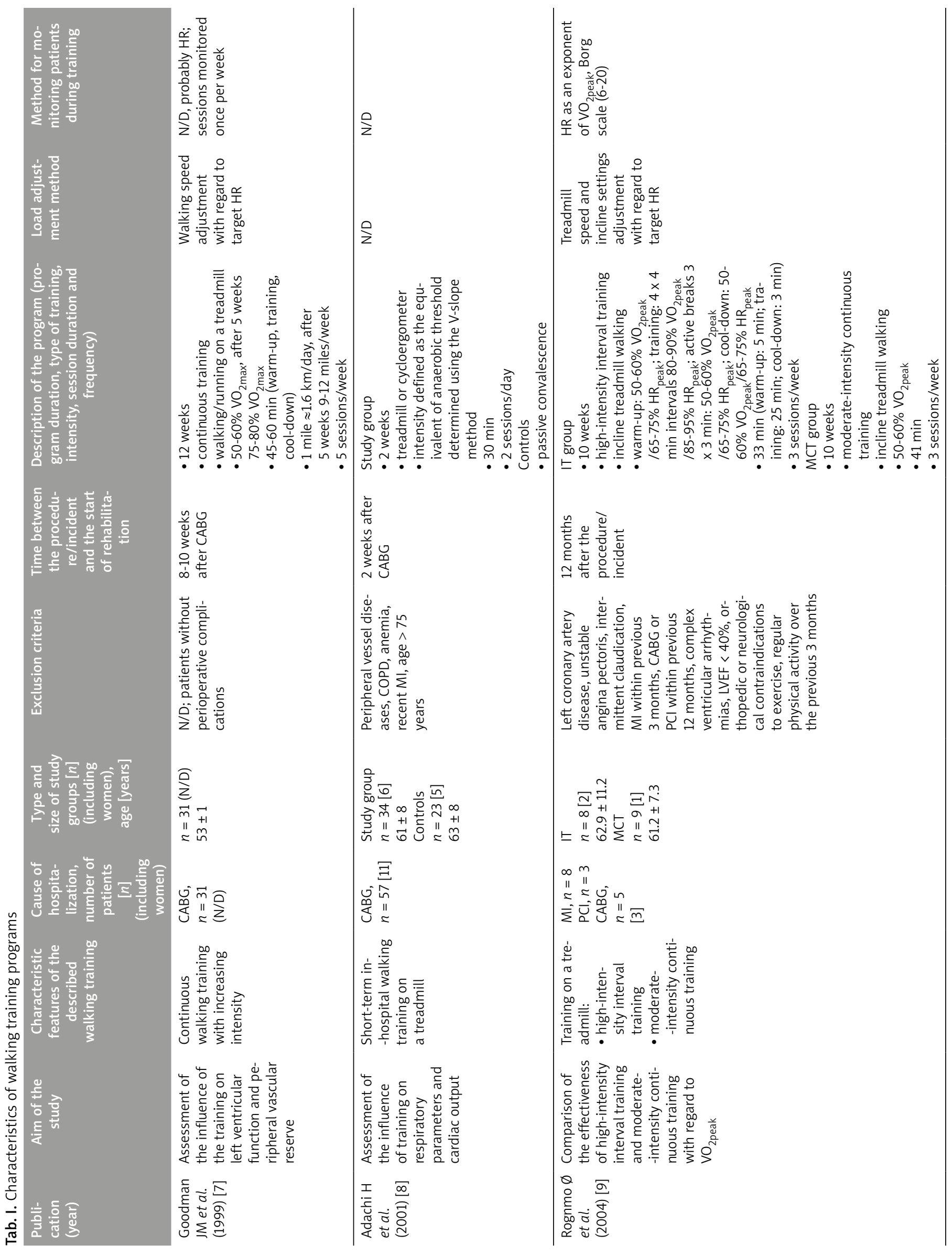




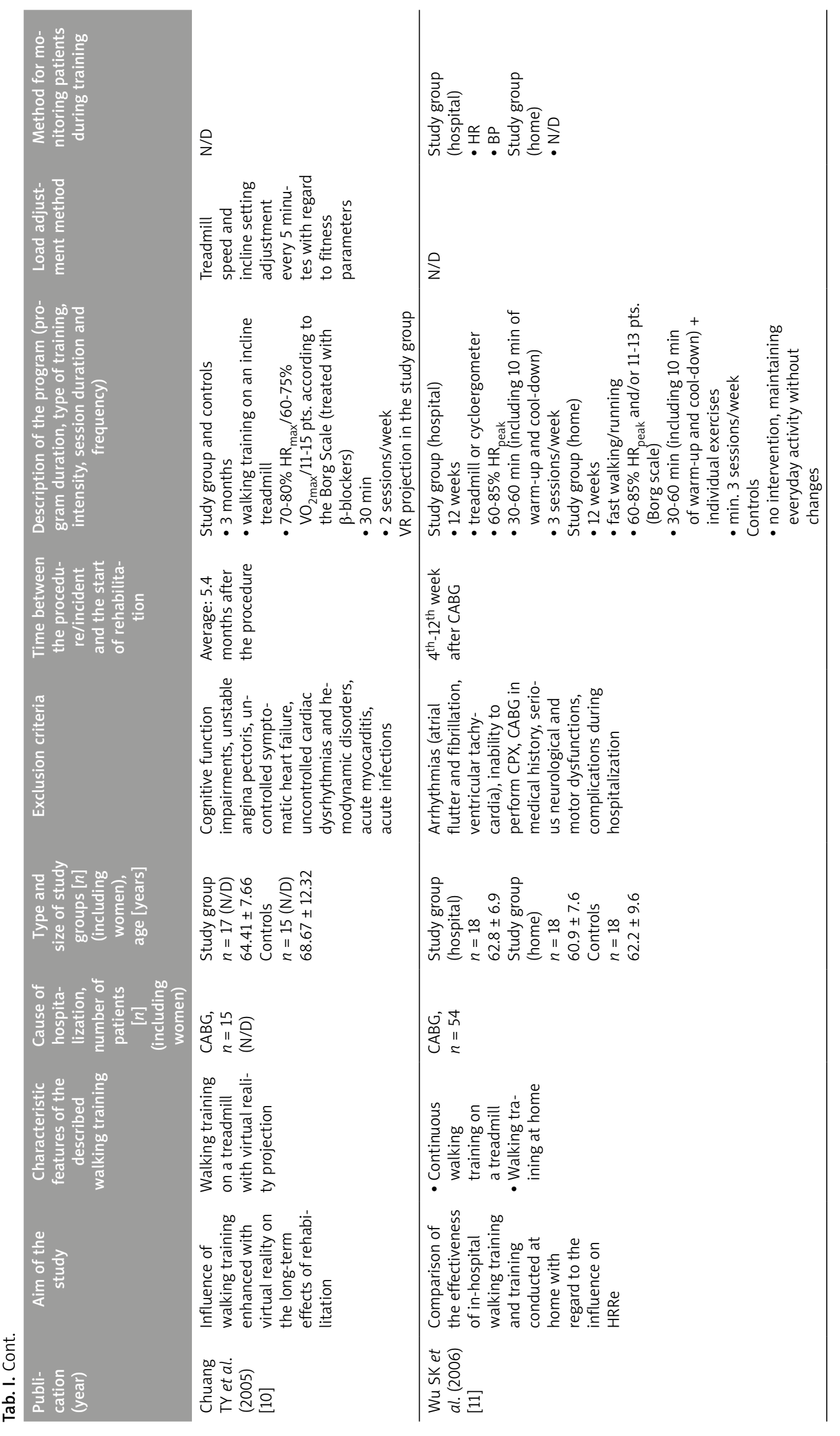




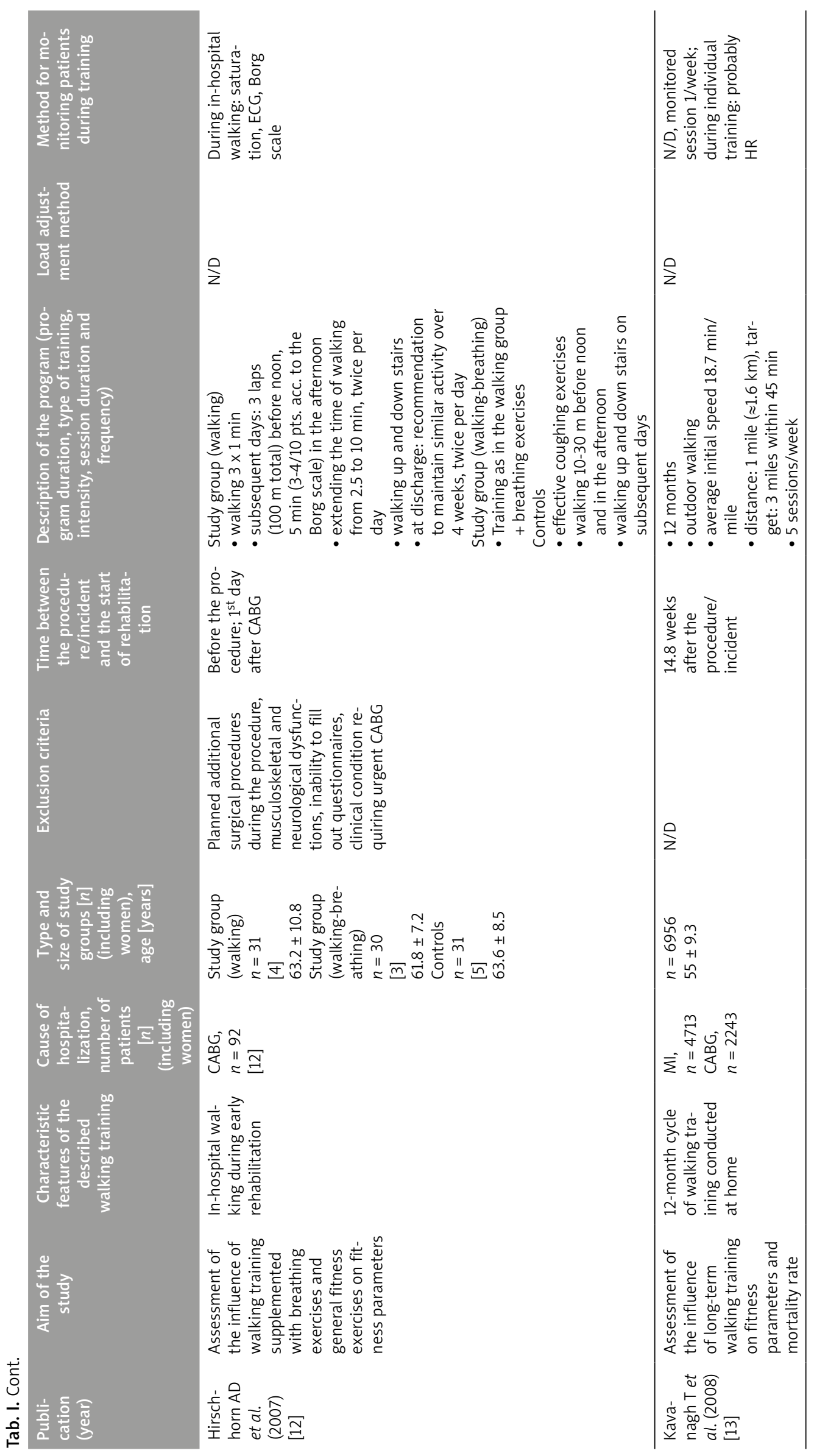




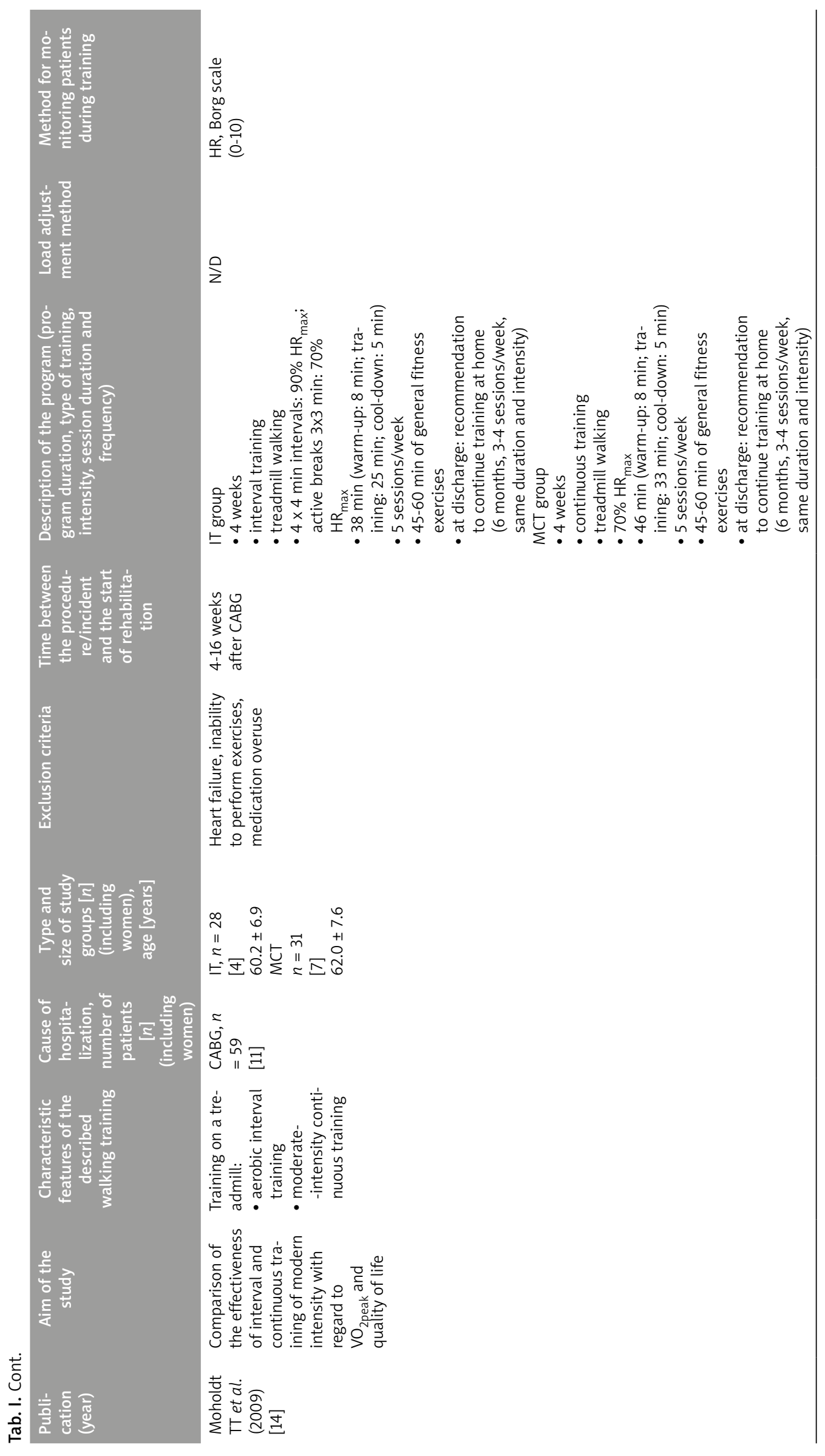




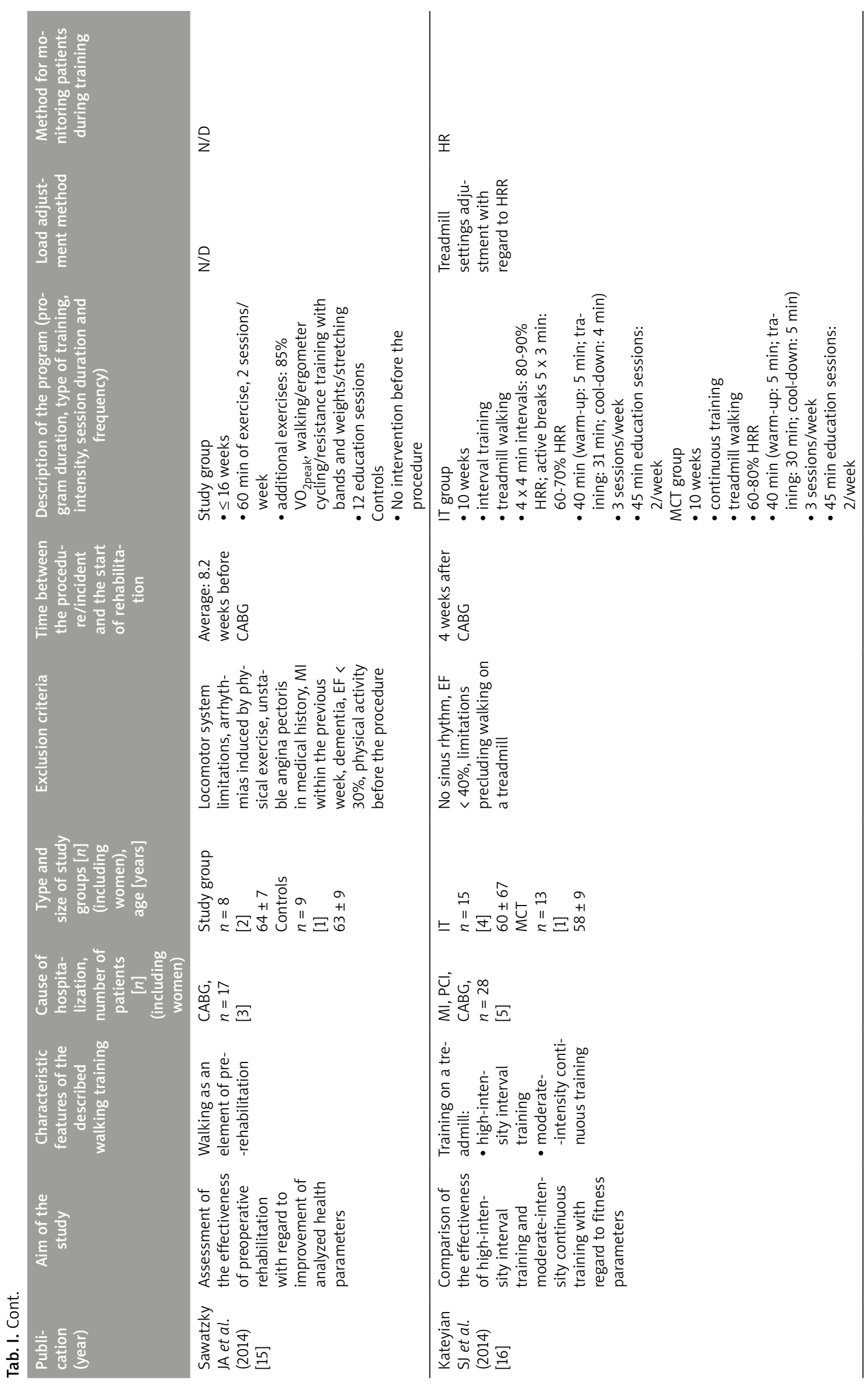




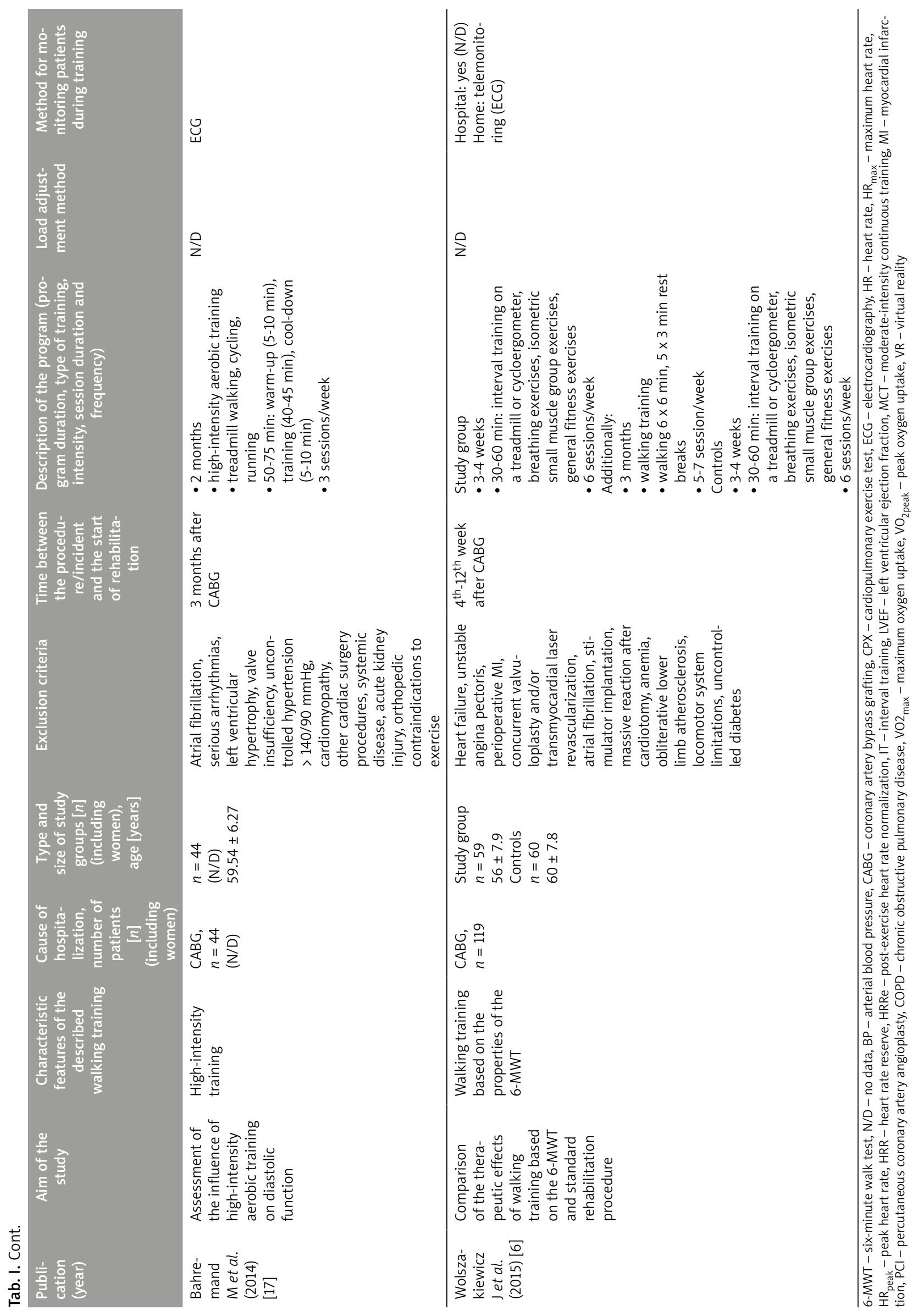


Tab. II. Statistically significant results of the analyzed training programs (results of final examinations in comparison to initial examinations)

\begin{tabular}{|c|c|}
\hline Publication (year) & Statistically significant results $(p<0.05)$ \\
\hline $\begin{array}{l}\text { Goodman JM et al. } \\
\text { (1999) [7] }\end{array}$ & $\begin{array}{l}\uparrow \text { maximum load by } 14 \% \text { (104 vs. } 119 \mathrm{~W}) \\
\uparrow \text { absolute } \mathrm{VO}_{2 \max } \text { by } 13 \% \text { (1497 vs. } 1691 \mathrm{ml} / \\
\text { min) and relative } \mathrm{VO}_{2 \mathrm{max}} \text { by } 11 \% \text { ( } 19 \mathrm{vs} . \\
21 \mathrm{ml} / \mathrm{kg} / \mathrm{min}) \\
\uparrow \mathrm{LVEF} \text { during submax exercise at } 40 \% \\
\mathrm{VO}_{2 \text { peak }}(60 \mathrm{vs} .63 \%) \text { and at } 70 \% \mathrm{VO}_{2 \text { peak }} \\
(61 \mathrm{vs} .64 \%) \\
\uparrow \mathrm{max} \text { blood flow through crural arteries by } \\
18 \% \text { and peak vascular flow by } 16 \% \\
\downarrow \text { lactate concentrations at the load of } 40 \% \\
\mathrm{VO}_{2 \text { peak }}(2.68 \mathrm{vs} .1 .83 \mathrm{ml} / \mathrm{kg} / \mathrm{min})\end{array}$ \\
\hline $\begin{array}{l}\text { Adachi } \mathrm{H} \text { et al. } \\
\text { (2001) [8] }\end{array}$ & 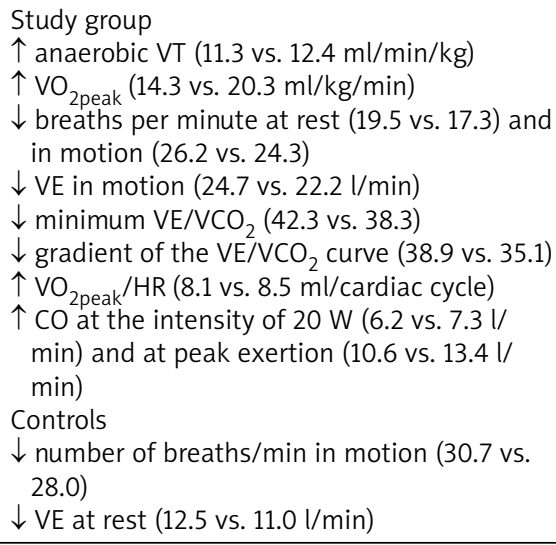 \\
\hline $\begin{array}{l}\text { Rognmo } \varnothing \text { et al. } \\
\text { (2004) [9] }\end{array}$ & $\begin{array}{l}\text { IT group } \\
\uparrow \text { absolute } \mathrm{VO}_{2 \text { peak }}(2.47 \mathrm{vs.} 2.92 \mathrm{l} / \mathrm{min}) \text { and } \\
\text { relative } \mathrm{VO}_{2 \text { peak }}(31.8 \mathrm{vs} .37 .8 \mathrm{ml} / \mathrm{kg} / \mathrm{min}) \\
\uparrow \text { peak ventilation }(74.3 \mathrm{vs} .88 .4 \mathrm{l} / \mathrm{min}) \\
\uparrow \text { walking speed in } \mathrm{CPX}(5.3 \mathrm{vs} .6 .8 \mathrm{kph}) \\
\downarrow \mathrm{CPX} \text { duration }(619 \mathrm{vs} .420 \mathrm{~s}) \\
\mathrm{VO}_{2 \text { peak }} \text { improvement by } 0.63 \% / \mathrm{session} \\
\mathrm{MCT} \text { group }^{\uparrow} \\
\uparrow \text { absolute } \mathrm{VO}_{2 \text { peak }}(2.61 \mathrm{vs.} .2 .81 \mathrm{l} / \mathrm{min}) \text { and } \\
\text { relative } \mathrm{VO}_{2 \text { peak }}(32.1 \mathrm{vs} .34 .8 \mathrm{ml} / \mathrm{kg} / \mathrm{min}) \\
\uparrow \text { peak ventilation }(80.2 \mathrm{vs} .86 .6 \mathrm{l} / \mathrm{min}) \\
\mathrm{VO}_{2 \text { peak }} \text { improvement by } 0.29 \% / \mathrm{session} \\
\end{array}$ \\
\hline $\begin{array}{l}\text { Chuang TY et al. } \\
\text { (2005) [10] }\end{array}$ & $\begin{array}{l}\text { Study group } \\
\uparrow \mathrm{VO}_{2 \text { peak }}(17.71 \mathrm{vs.} 22.47 \mathrm{ml} / \mathrm{kg} / \mathrm{min}) \\
\uparrow \mathrm{MET}_{\text {peak }}(5.06 \text { vs. } 6.42 \mathrm{MET})\end{array}$ \\
\hline $\begin{array}{l}\text { Wu SK et al. } \\
\text { (2006) [11] }\end{array}$ & 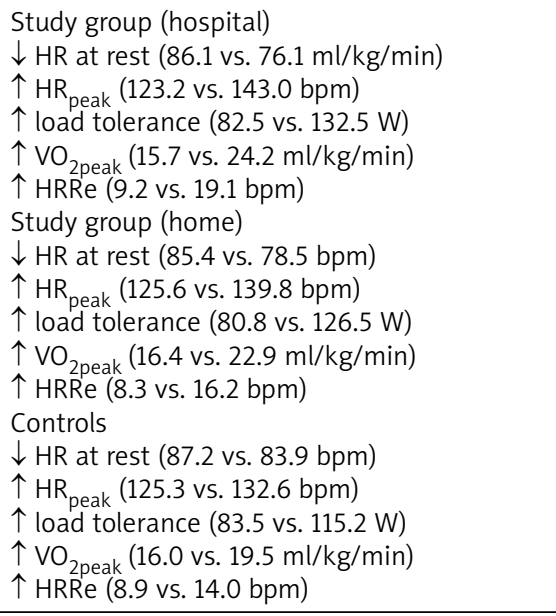 \\
\hline $\begin{array}{l}\text { Hirschhorn AD et } \\
\text { al. (2007) [12] }\end{array}$ & $\begin{array}{l}\uparrow \text { 6-MWT distance at discharge in groups } \\
\text { undergoing walking training, walking and } \\
\text { breathing exercises, and controls (respecti- } \\
\text { vely: } 444 \pm 84,431 \pm 98 \text {, and } 377 \pm 90 \mathrm{~m} \text { ) }\end{array}$ \\
\hline
\end{tabular}

\begin{tabular}{|c|c|}
\hline Publication (year) & Statistically significant results $(p<0.05)$ \\
\hline $\begin{array}{l}\text { Kavanagh T et al. } \\
\text { (2008) [13] }\end{array}$ & $\begin{array}{l}\downarrow \text { HR at rest in patients with and without } \\
\beta \text {-blocker therapy (respectively by } 2.1 \text { and } \\
5.5 \text { bpm) } \\
\uparrow \mathrm{HR}_{\text {peak }} \text { in patients with and without } \\
\beta \text {-blocker therapy (respectively by } 4.2 \text { and } \\
3.2 \text { bpm) } \\
\downarrow \text { SBP and DBP at rest (respectively: by } 1.0 \\
\text { and } 1.8 \mathrm{mmHg} \text { ) } \\
\uparrow \text { peak SBP (by } 7.2 \mathrm{mmHg} \text { ) } \\
\downarrow \text { peak DBP (by } 2.0 \mathrm{mmHg} \text { ) } \\
\uparrow \mathrm{VO}_{2 \text { peak }} \text { (by } 4.8 \mathrm{ml} / \mathrm{kg} / \mathrm{min} \text { ) } \\
\uparrow \text { distance (by } 2.1 \mathrm{miles} \text { ) } \\
\uparrow \text { walking speed (by } 2.5 \text { miles } / \mathrm{min} \text { ) }\end{array}$ \\
\hline $\begin{array}{l}\text { Moholdt TT et al. } \\
\text { (2009) [14] }\end{array}$ & 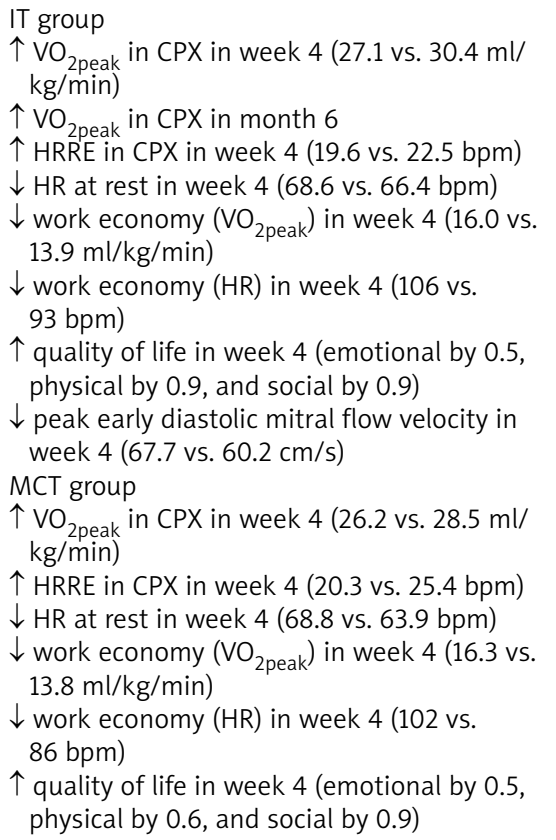 \\
\hline $\begin{array}{l}\text { Sawatzky JA et al. } \\
\text { (2014) [15] }\end{array}$ & $\begin{array}{l}\text { Study group } \\
\uparrow 6 \text {-MWT distance (initial: } 342 \pm 79 \mathrm{~m} \text {, before } \\
\text { the procedure: } 474 \pm 101 \mathrm{~m} \text {, after the proce- } \\
\text { dure: } 487 \pm 106 \mathrm{~m} \text { ) } \\
\downarrow \text { time of walking } 5 \mathrm{~m} \text { (initial: } 5.5 \mathrm{~s} \text {, before the } \\
\text { procedure: } 4.0 \mathrm{~s} \text {, after the procedure: } 3.7 \mathrm{~s} \text { ) } \\
\uparrow \text { percentage of participation in postoperative } \\
\text { rehabilitation in comparison to the control } \\
\text { group }(100 \% \text { vs. } 43 \%)\end{array}$ \\
\hline $\begin{array}{l}\text { Kateyian SJ et al. } \\
\text { (2014) [16] }\end{array}$ & $\begin{array}{l}\text { IT group } \\
\downarrow \text { DBP at rest }(78 \mathrm{vs} .71 \mathrm{mmHg}) \\
\downarrow \text { HR in the } 2^{\text {nd }} \text { stage of CPX }(98 \mathrm{vs} .90 \mathrm{bpm}) \\
\uparrow \text { relative oxygen uptake at the anaerobic } \\
\text { threshold (14.1 vs. } 17.1 \mathrm{ml} / \mathrm{kg} / \mathrm{min}) \\
\uparrow \text { absolute oxygen uptake at the anaerobic } \\
\text { threshold }(1315 \mathrm{vs} .1546 \mathrm{ml} / \mathrm{kg} / \mathrm{min}) \\
\uparrow \text { relative } \mathrm{VO}_{2 \text { peak }}(22.4 \mathrm{vs.} 26.0 \mathrm{ml} / \mathrm{kg} / \mathrm{min}) \\
\text { and absolute } \mathrm{VO}_{2 \text { peak }}(2025 \mathrm{vs} .2309 \mathrm{ml} / \mathrm{min}) \\
\uparrow \text { peak oxygen pulse }(14.2 \mathrm{vs} .15 .8 \mathrm{ml} / \mathrm{beat}) \\
\mathrm{MCT} \text { group } \\
\downarrow \text { HR in the } 2^{\text {nd }} \text { stage of CPX }(95 \mathrm{vs} .87 \mathrm{bpm}) \\
\uparrow \text { relative } \mathrm{VO}_{2 \text { peak }}(21.8 \mathrm{vs} .23 .5 \mathrm{ml} / \mathrm{kg} / \mathrm{min}) \\
\text { and absolute } \mathrm{VO}_{2 \text { peak }}(1982 \mathrm{vs} .2119 \mathrm{ml} / \mathrm{min}) \\
\uparrow \text { peak oxygen pulse }(14.6 \mathrm{vs} .16 .2 \mathrm{ml} / \mathrm{beat})\end{array}$ \\
\hline
\end{tabular}


Tab. II. Cont.

\begin{tabular}{|c|c|}
\hline Publication (year) & Statistically significant results $(p<0.05)$ \\
\hline $\begin{array}{l}\text { Bahremand M et } \\
\text { al. (2014) [17] }\end{array}$ & $\begin{array}{l}\downarrow \text { time of isovolumic relaxation time ( } 94 \text { vs. } \\
89 \text { ms) } \\
\uparrow \text { relation between peak early diastolic and late } \\
\text { diastolic mitral flow velocity ( } 0.94 \text { vs. } 1.04) \\
\uparrow \text { relation between mitral A inflow duration and } \\
\text { pulmonary A inflow duration ( } 1.07 \text { vs. } 1.12 \text { ) } \\
\text { Unchanged ratio between the peak velocities } \\
\text { of systolic flow through the left superior } \\
\text { pulmonary vein and diastolic flow (0.89 vs. } \\
1.04) \\
\text { Unchanged ratio between the early diastolic } \\
\text { transmitral flow velocity and the velocity of } \\
\text { early diastolic mitral annular motion (10.79 } \\
\text { vs. } 10.22) \\
\uparrow \text { deceleration time (192.71 vs. } 219.00 \text { ms) } \\
\uparrow \text { velocity of early diastolic mitral annular } \\
\text { motion (5.90 vs. } 6.77 \text { cm/s) } \\
\downarrow \text { degree of diastolic dysfunction (1.30 vs. } \\
0.88)\end{array}$ \\
\hline
\end{tabular}

\begin{tabular}{|c|c|}
\hline Publication (year) & Statistically significant results $(p<0.05)$ \\
\hline $\begin{array}{l}\text { Wolszakiewicz J et } \\
\text { al. (2015) [6] }\end{array}$ & 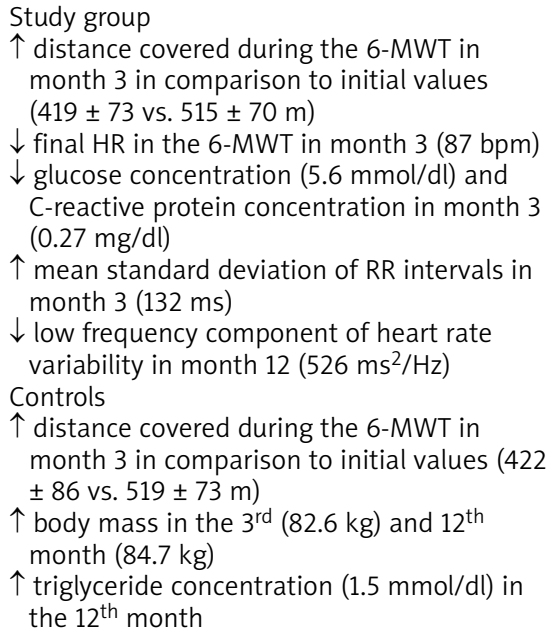 \\
\hline
\end{tabular}

6-MWT - six-minute walk test, BP - arterial blood pressure, CO - cardiac output, CPX - cardiopulmonary exercise test, DBP - diastolic arterial blood pressure, HR heart rate, $\mathrm{HR}_{\text {peak }}$ - peak heart rate, HRRe - post-exercise heart rate normalization, IT - interval training, LVEF - left ventricular ejection fraction, $M C T$ - moderate-intensity continuous training, MET - metabolic equivalent, SBP - systolic arterial blood pressure, $\mathrm{VCO}_{2}-$ carbon dioxide production, VE - minute volume, VE/VCO - ventilation equivalent for carbon dioxide, $\mathrm{VO}_{2 \max }$ - maximum oxygen uptake, $\mathrm{VO}_{2 \text { peak }}$ - peak oxygen uptake, $\mathrm{VO}_{2 \text { peak }} / \mathrm{HR}$ - oxygen pulse, $\mathrm{VT}$ - ventilatory threshold

The discomfort has a significant impact on the breathing pattern, which becomes shallow and accelerated; nonetheless, the respiratory rhythm normalizes gradually over time. This process is probably accelerated by physical activity, as illustrated by the reduced gradient of the $\mathrm{VE}-\mathrm{VCO}_{2}$ curve in the study group undergoing walking training (Table II). Based on the obtained data, the authors concluded that walking training has a positive impact on the ventilation/ perfusion ratio during physical activity. The value of the minute volume of the heart was another clinically significant parameter shown to have improved in the aforementioned study. According to the authors, the dilation of peripheral blood vessels and the increase in their sensitivity to catecholamines resulting from physical activity are the most probable causes of increased cardiac output in patients undergoing walking training.

Hirschhorn et al. [12] verified the therapeutic effectiveness of walking training as well as walking training in combination with breathing exercises in the early stages of rehabilitation. The studied patients were assigned to one of three groups: the first adhered to standard rehabilitation procedures, the second participated in walking training alone, while the third participated in walking training combined with breathing exercises (Table I). Training intensity in all three groups was the same and was described as moderate. Control examinations in the form of a sixminute walk test (6-MWT) and measurements of the vital capacity of the lungs and quality of life were conducted preoperatively, on discharge, and 4 weeks after discharge. The patients participating in walking training (groups 2 and 3) had significantly better results of the 6-MWT conducted on discharge in comparison with the group adhering to standard procedures (Table II). Concurrently, no ad- ditional benefits were noted with regard to the analyzed parameters (including the vital capacity of the lungs and quality of life) that would result from the introduction of the additional program of breathing and general fitness exercises in group 3. It was also a surprise that the subsequent examinations, performed 4 weeks after discharge, showed no statistically significant differences between the groups in terms of the results of the 6-MWT. The authors explain this phenomenon in two ways: (1) regardless of the procedures employed in the early stages of rehabilitation, fitness parameters of all CABG patients gradually normalize; (2) the therapeutic effect achieved in the early stages of hospital rehabilitation requires reinforcement, e.g., by referring patients to a second stage of cardiac rehabilitation without delay. The authors suggest that the habits and procedures learned by the patients during the hospital stage could be used by them to transition smoothly into the next stage of rehabilitation.

The beneficial modulating impact of walking training on the respiratory and cardiovascular systems can also be observed in the nervous system. The important issue of the function of the autonomic nervous system in patients undergoing CABG was analyzed by Wu et al. [11]. The common symptoms of a dysfunction of this system in $C A B G$ patients include increased resting heart rate and limited heart rate variability [30]. The rate of post-exercise heart rate normalization is another important indicator of the functioning of the autonomic nervous system. The prognostic value of these parameters has been described along with the favorable effect of physical activity on their normalization [31, 32]. It should be stressed that the authors observed a significant improvement in all three study groups (undergoing rehabilitation in the 
hospital, at home, and controls), but significantly more improvement was achieved by patients undergoing inhospital rehabilitation in comparison to the other groups. The authors explain the improvement of post-exercise heart rate normalization, reduction of resting heart rate, and increase of maximum heart rate by the restoration of balance between the sympathetic and parasympathetic components of the autonomic nervous system [11].

The influence of walking training on the functioning of the nervous system was also one of the issues examined by Chuang et al. [10]. The novelty of the walking training program used by the authors consisted in the addition of virtual reality projection to the training sessions (Table I). The physiotherapist adjusted the speed and incline settings of the treadmill every 5 minutes based on the fitness parameters of the patient. Every change in the treadmill parameters was reflected in the virtual reality displayed by the projector, which consisted in a $5 \mathrm{~km}$ route, alternately straight and curved, supplemented with elements of scenery (grass, trees). Patients participating in walking training enhanced by the projection of virtual reality had significantly better values of $\mathrm{VO}_{2 \text { peak }}$ and peak MET (Table II). According to the authors, the results stem from increased motivation levels in the group stimulated with virtual reality and from reflexive, deep, global neurorelaxation which may contribute to reducing the level of oxidative stress and lactate concentration as well as to maintaining exercise over longer periods of time with regard to aerobic metabolism. In consequence, these factors may have a significant influence on the improvement of fitness parameters.

A decided majority of walking training programs described in the literature require the use of a treadmill [7-11, $14,16,17]$. An alternative method of rehabilitation which does not require the use of special equipment consists of regular walking on the premises of the rehabilitation center, planned on the basis of the 6-MWT. For example, Wolszakiewicz et al. designed a walking training program for CABG patients based on the 6-MWT [6]. The proposed program not only had a favorable effect on extending the walking distance in control examinations (Table II) but also showed that low initial walking distance is the only independent factor influencing its increase in the study group.

The benefits of walking training are not limited to the fact that it can be performed without the need for a special treadmill; it can also be employed in a wide spectrum of studies: from short-term sessions of preoperative rehabilitation [15] to long-term training conducted, e.g., to evaluate the risk of death [13]. A pilot pre-rehabilitation program for patients awaiting planned CABG (Table I) was designed by Sawatzky et al. [15]. According to the authors, the waiting time provides the perfect opportunity to commence activities aimed at preoperative improvement of relatively lowrisk patients without contraindications for low-intensity physical activity. Pre-rehabilitation can have a positive effect on the safety and outcome of the procedure as well as encourage the patient to participate in properly selected and supervised physical activity after the procedure. As indi- cated by pilot studies (Table II), walking training can be successfully used as an element of this form of rehabilitation.

A 10-year observational study of patients after myocardial infarction and CABG who had undergone a 1-year cycle of walking training, conducted by Kavanagh et al. [13], demonstrated that, in the studied group of men, prolonging the march distance by 1 mile $(\approx 1.6 \mathrm{~km})$ led to a decrease of cardiac death risk by $20 \%$. Distance improvements of 1.3-2.8 miles and $2.8+$ miles were associated with reductions in the risk of cardiac-related death of, respectively, $24 \%$ and $48 \%$. In the study group, walking distance improvement (Table II) was a strong, independent predictor for good prognosis, stronger than $\mathrm{VO}_{2 \text { peak }}$.

\section{Discussion}

According to the recommendations of the American College of Sports Medicine (ACSM), physical training is the best method for maintaining good health, provided that it is adjusted to individual needs and capabilities. The FITT principle defines the fundamental components which must be considered when individualizing rehabilitation programs: frequency, intensity, type, time/duration, and progression $[4,5]$.

In accordance with the ACSM's recommendations, rehabilitation exercises should be performed on most days of the week [e.g., 4-7]. Patients with low exercise tolerance can perform their everyday sessions in the form of 1-10 min intervals $[4,5]$.

The frequency of the training sessions in the analyzed programs varied greatly, ranging from 2 to 7 sessions per week (Table I), conducted once [6, 7, 9-11, 13-17] or twice per day $[8,12]$. A separate issue concerns the early stage of rehabilitation: it most often began with 2-4 short sessions per day, followed by a regimen of 2 longer sessions per day [5]. This scheme was employed by Adachi et al. [8] and Hirschhorn et al. [12].

The intensity of walking training programs for patients after CABG constitutes the greatest controversy. The ACSM recommends that it should fall within the range of 11-16 points of perceived exertion (on a scale of 6-20) or $40-80 \%$ of exercise capacity defined by heart rate reserve, oxygen uptake reserve, or peak oxygen uptake. The maximum intensity of the recommended exercises cannot exceed the values of heart rate corresponding to myocardial ischemia. Also, patients at the early stages of rehabilitation after CABG should not exceed the values of exercise heart rate of more than $30 \mathrm{bpm}$ in comparison to resting heart rate $[4,5]$. In view of these guidelines, the use of training programs with intensity reaching $95 \%$ of peak heart rate [9], 90\% of maximum heart rate [14], or $90 \%$ of heart rate reserve [16] appears risky. Most authors employing high-intensity training programs $[9,14$, 16] provide detailed analyses of their effectiveness, but fail to examine the question of their safety. In many of these programs, the patient's condition is monitored using heart rate and the Borg scale $[9,14,16]$ or heart rate alone [16]. Electrocardiogram monitoring was employed 
only by Hirschorn et al. [12] during the early stage of inhospital rehabilitation, Bahremand et al. [17] during highintensity training, and Wolszakiewicz et al. [6] in the form of telemonitoring. Many of the reports feature no information concerning the method of patient supervision, or the information is unclear $[7,8,10,13,15]$.

Walking training is rarely the sole method of rehabilitation: usually, it is accompanied by various other activities $[6,11,12,14,15,17]$. Due to the complexity of the programs, there are significant differences regarding the duration of individual sessions: from the average of $30 \mathrm{~min} /$ day to $75 \mathrm{~min} /$ day [6-17]. For cardiovascular patients, the ACSM recommends a target session duration of 20-60 minutes, including 5-10 minutes of warm-up and cool-down in the form of static stretching and exercises improving the extent of movement. However, their intensity should not exceed $40 \%$ of oxygen uptake reserve [4, 5]. Most of the analyzed authors adhere to these recommendations (Table I); only Bahremand et al. [17] employed sessions of up to $75 \mathrm{~min}$ utes. During the early stage of cardiac rehabilitation, the duration of a single dose of exercise (provided that it is well tolerated by the patient) should be 3-5 minutes followed by a period of rest which may take the form of slower walking. The target ratio of exercise to rest should be $2: 1$ [4, 5]. A program for the early rehabilitation of patients after CABG in accordance with the above recommendations was presented by Hirschhorn et al. [12].

Apart from the frequency, intensity, and duration of the sessions, the progression of training loads is one of the more important elements of rehabilitation. According to the guidelines $[4,5]$, the progression should be individualized and based on factors such as initial fitness capacity, patient motivation and goals, any concomitant symptoms, and locomotor system limitations. In practice, the training load may be increased by gradually extending the walking distance [13] and then shortening its duration (increasing the walking speed) [7], increasing the walking speed and/ or treadmill incline settings $[9,10,16]$, extending the duration of training $[6,14,17]$, and, in the early stage of rehabilitation, extending the walking distance without increasing the speed [12].

For cardiac rehabilitation, the guidelines $[4,5]$ recommend aerobic exercises. Each session should consist of rhythmic exercises for large muscle groups, which are indispensable for maintaining or restoring normal body weight. However, the crux of each rehabilitation program should consist of exercises aimed at improving general fitness with the use of ergometers: upper and/or lower body classic cycloergometers $[6,8,11,15]$ or horizontal, elliptical, and rowing ergometers and treadmills [6-11, 14, 16, 17], or exercises without the use of special equipment, consisting of walking $[12,13,15]$ or stair climbing [12]. Notwithstanding, at least 3 months of sternal protection are required for patients subjected to sternotomy in order to undergo coronary artery bypass grafting [18]. In view of these recommendations, some forms of rehabilitation, such as running $[7,11,17]$ or cycling [17], seem controversial.
As far as the technical aspects of the training programs are concerned, it is noteworthy that the authors used numerous exclusion criteria (Table I), resulting in the selection of patients in relatively good clinical condition for the study groups. Some of these criteria include procedures, conditions, and diseases typical for most cardiovascular patients, including those undergoing CABG, e.g.: arterial hypertension above $140 / 90 \mathrm{mmHg}$, left ventricular hypertrophy, cardiomyopathy [17]; heart failure, unstable angina pectoris, myocardial infarction, valvuloplasty, stimulator implantation, uncontrolled diabetes [6]; age above 75 years, peripheral vessel diseases, COPD, anemia [8]; left coronary artery disease, intermittent claudication, myocardial infarction within the past 3 months, CABG or PCI within the past 12 months, complex ventricular arrhythmias, LVEF < 40\%, orthopedic or neurological limitations, or participation in regular physical activity within the previous 3 months [9]. When it comes to the clinical characteristics of patients, it is notable that the participants of some of the programs were characterized by good initial general condition, e.g., left ventricular ejection fraction of approx. 60\% [8], and were relatively young and fit [16]. Many study groups were mixed in terms of sex [8, 9, 12, 14-16] and heterogeneous with regard to nosological entities: patients after $C A B G$ and after myocardial infarction $[9,13]$ or CABG, myocardial infarction, and $\mathrm{PCl}$ [16]. Interpretation of the study results is also impeded by the alternating use of treadmill and cycloergometer training within one study group (even if the same intensity of training is maintained) $[6,8,11,15]$. Furthermore, the credibility of some of the results is undermined by the lack of a control group [7, 13, 17].

\section{Conclusions}

Walking training has been applied for many years in patients undergoing CABG procedures. Many types of walking training have been designed; they vary with regard to intensity and are supplemented with different kinds of activities. Nonetheless, the methodology of training requires continuous improvement, particularly in terms of load dosage and session monitoring. This is of particular importance with regard to the rehabilitation of high-risk patients burdened with numerous concomitant diseases, for whom the intensity of some of the described programs may prove too high. Walking training is an excellent alternative to the widely employed cycloergometer training; therefore, new walking training protocols must be designed and implemented, especially considering situations in which cycloergometer training cannot be conducted for various reasons.

\section{Disclosure}

Authors report no conflict of interest.

\section{References}

1. Rodriguez AE, Baldi J, Fernández Pereira C, Navia J, Rodriguez Alemparte M, Delacasa A, Vigo F, Vogel D, O'Neill W, Palacios IF. Five-year follow-up of the Argentine randomized trial of coronary angioplasty with stenting versus 
coronary bypass surgery in patients with multiple vessel disease (ERACI II). J Am Coll Cardiol 2005; 46: 582-588.

2. Serruys PW, Morice MC, Kappetein AP, Colombo A, Holmes DR, Mack MJ, Stĺhle E, Feldman TE, van den Brand M, Bass EJ, Van Dyck N, Leadley K, Dawkins KD, Mohr FW. Percutaneous coronary intervention versus coronary-artery bypass grafting for severe coronary artery disease. N Engl I Med 2009; 360: 961-972.

3. Dominiak M, Drożdż J. Operacja pomostowania aortalno-wieńcowego pozostaje optymalnym leczeniem u pacjentów z zaawansowaną postacią wielonaczyniowej choroby wieńcowej - wnioski z badań wieloośrodkowych. Kardiochir Torakochir Pol 2009; 6: 181-186.

4. ACSM's Guidelines for Exercise Testing and Prescription. 9th ed. Lippincott Williams \& Wilkins Health, Philadelphia 2014.

5. ACSM's Guidelines for Exercise Testing and Prescription. 8th ed. Lippincott Williams \& Wilkins Health, Philadelphia 2010.

6. Wolszakiewicz J, Piotrowicz E, Foss-Nieradko B, Dobraszkiewicz-Wasilewska B, Piotrowicz R. The novel model of exercise walking training in post coronary artery bypass grafting patients. Kardiol Pol 2015; 73: 118-126.

7. Goodman JM, Pallandi DV, Reading JR, Plyley MJ, Liu PP, Kavanagh T. Central and peripheral adaptations after 12 weeks of exercise training in post-coronary artery bypass surgery patients. J Cardiopulm Rehabil 1999; 19: 144-150.

8. Adachi H, Itoh H, Sakurai S, Takahashi T, Toyama T, Naito S, Hoshizaki H, Oshima S, Taniguchi K, Kato M, Fu LT, Kato K. Short-term physical training improves ventilatory response to exercise after coronary arterial bypass surgery. Jpn Circ J 2001; 65: 419-423.

9. Rognmo R̆, Hetland E, Helgerud J, Hoff J, Slřrdahl SA. High intensity aerobic interval exercise is superior to moderate intensity exercise for increasing aerobic capacity in patients with coronary artery disease. Eur J Cardiovasc Prev Rehabil 2004; 11: 216-222.

10. Chuang TY, Sung WH, Lin CY. Application of a virtual reality-enhanced exercise protocol in patients after coronary bypass. Arch Phys Med Rehabil 2005; 86: 1929-1932.

11. Wu SK, Lin YW, Chen CL, Tsai SW. Cardiac rehabilitation vs. home exercise after coronary artery bypass graft surgery: a comparison of heart rate recovery. Am J Phys Med Rehabil 2006; 85: 711-717.

12. Hirschhorn AD, Richards D, Mungovan SF, Morris NR, Adams L. Supervised moderate intensity exercise improves distance walked at hospital discharge following coronary artery bypass graft surgery - a randomised controlled trial. Heart Lung Circ 2008; 17: 129-138.

13. Kavanagh T, Hamm LF, Beyene J, Mertens DJ, Kennedy J, Campbell R, Fallah S, Shephard RJ. Usefulness of improvement in walking distance versus peak oxygen uptake in predicting prognosis after myocardial infarction and/or coronary artery bypass grafting in men. Am J Cardiol 2008; 101: 1423-1427.

14. Moholdt TT, Amundsen BH, Rustad LA, Wahba A, Lřvř KT, Gullikstad LR, Bye A, Skogvoll E, Wislřff U, Slřrdahl SA. Aerobic interval training versus continuous moderate exercise after coronary artery bypass surgery: a randomized study of cardiovascular effects and quality of life. Am Heart J 2009; 158: 1031-1037.

15. Sawatzky JA, Kehler DS, Ready AE, Lerner N, Boreskie S, Lamont D, Luchik D, Arora RC, Duhamel TA. Prehabilitation program for elective coronary artery bypass graft surgery patients: a pilot randomized controlled study. Clin Rehabil 2014; 28: 648-657.

16. Keteyian SJ, Hibner BA, Bronsteen K, Kerrigan D, Aldred HA, Reasons LM, Saval MA, Brawner CA, Schairer JR, Thompson TM, Hill J, McCulloch D, Ehrman JK. Greater improvement in cardiorespiratory fitness using higher- intensity interval training in the standard cardiac rehabilitation setting. J Cardiopulm Rehabil Prev 2014; 34: 98-105.

17. Bahremand M, Salehi N, Rai A, Rezaee M, Raeisei AA. Cardiac rehabilitation program with high intensity aerobic exercise can reverse diastolic impairment in patients undergoing coronary artery bypass surgery. Galen Med 2014; 3: 102-108

18. Fletcher GF, Balady GJ, Amsterdam EA, Chaitman B, Eckel R, Fleg J, Froelicher VF, Leon AS, Pińa IL, Rodney R, Simons-Morton DA, Williams MA, Bazzarre $T$. Exercise standards for testing and training: a statement for healthcare professionals from the American Heart Association. Circulation 2001; 104 1694-1740.

19. Myers J, Prakash M, Froelicher V, Do D, Partington S, Atwood JE. Exercise capacity and mortality among men referred for exercise testing. N Engl Med 2002; 346: 793-801

20. Kavanagh T, Mertens DJ, Hamm LF, Beyene J, Kennedy J, Corey P, Shephard RJ. Prediction of long-term prognosis in 12169 men referred for cardiac rehabilitation. Circulation 2002; 106: 666-671.

21. Arena R, Humphrey R. Relationship between ventilatory expired gas and cardiac parameters during symptom-limited exercise testing in patients with heart failure. J Cardiopulm Rehabil 2001; 21: 130-134.

22. Myers J, Wagner D, Schertler T, Beer M, Luchinger R, Klein M, Rickli H, Muller P, Mayer K, Schwitter J, Dubach P. Effects of exercise training on left ventricular volumes and function in patients with nonischemic cardiomyopathy: application of magnetic resonance myocardial tagging. Am Heart 2002; 144: 719-725.

23. Smart N, Haluska B, Jeffriess L, Marwick TH. Exercise training in systolic and diastolic dysfunction: effects on cardiac function, functional capacity, and quality of life. Am Heart J 2007; 153: 530-536.

24. Arbab-Zadeh A, Dijk E, Prasad A, Fu Q, Torres P, Zhang R, Thomas JD, Palmer D, Levine BD. Effect of aging and physical activity on left ventricular compliance. Circulation 2004; 110: 1799-1805.

25. Stewart KJ, Ouyang P, Bacher AC, Lima S, Shapiro EP. Exercise effects on cardiac size and left ventricular diastolic function: relationships to changes in fitness, fatness, blood pressure and insulin resistance. Heart 2006; 92 893-898.

26. Loimaala A, Groundstroem K, Rinne M, Nenonen A, Huhtala H, Parkkari J, Vuori I. Effect of long-term endurance and strength training on metabolic control and arterial elasticity in patients with type 2 diabetes mellitus. Am J Cardiol 2009; 103: 972-977.

27. Korzeniowska-Kubacka I, Bilińska M, Michalak E, Kuśmierczyk-Droszcz B, Dobraszkiewicz-Wasilewska B, Piotrowicz R. Influence of exercise training on left ventricular diastolic function and its relationship to exercise capacity in patients after myocardial infarction. Cardiol J 2010; 17: 136-142.

28. Reading JL, Goodman JM, Plyley MJ, Floras JS, Liu PP, McLaughlin PR, Shephard RJ. Vascular conductance and aerobic power in sedentary and active subjects and heart failure patients. J Appl Physiol 1993; 74: 567-573.

29. Snell PG, Martin WH, Buckey JC, Blomqvist CG. Maximal vascular leg conductance in trained and untrained men. J Appl Physiol 1987; 62: 606-610.

30. Hallas CN, Thornton EW, Fabri BM, Fox MA, Jackson M. Predicting blood pressure reactivity and heart rate variability from mood state following coronary artery bypass surgery. Int J Psychophysiol 2003; 47: 43-55.

31. Pierpont GL, Stolpman DR, Gornick CC. Heart rate recovery post-exercise as an index of parasympathetic activity. J Auton Nerv Syst 2000; 80: 169-174.

32. Pierpont GL, Voth EJ. Assessing autonomic function by analysis of heart rate recovery from exercise in healthy subjects. Am J Cardiol 2004; 94: 64-68. 